as a basis for their classification. Thus Bichat, who was a profound student of morbid anatomy, emphasised the importance of relating the specificity of each disease to the nature of the fundamental tissues attacked rather than to the disturbances in individual organs.

The views of Broussais, who rejected the conception of diseases as entities and insisted that disorders of function should receive more attention, were supported by the contemporary school of Vienna, which maintained that the task of the physician was to identify in the patient the various individual lesions of morbid anatomy.

Meanwhile, the leading English-speaking physicians, such as Addison, Bright and Hodgkin in London, and Graves, Stokes, Cheyne and Adams in Dublin, were bringing about real advances in clinical medicine by the clear demonstration of diseases and clinical states with which their names are associated.

The great movement in German medical thought which culminated in the middle of the nineteenth century was associated with a strong reaction against all claims of specificity based on the mere assembling of associated symptoms. Virchow in particular maintained that French and British ontology had impeded real progress in scientific medicine, and believed that with its destruction the use of a treatment falsely called specific would also disappear.

On the other hand, the doctrines of Sydenham and the leading representatives of the French school, among whom Sir Frederick omits to mention Bretonneau, to whom Trousseau was indebted for his views on specificity, were later confirmed by the discoveries of Pasteur, whose laboratory work did more to clarify medical thought than most of the doctrines emanating from the medical schools, inasmuch as he replaced a mysterious something by the highly objective micro-organism as the cause of certain infectious diseases. Sir Frederick, however, pointed out that the presence of bacillus or virus, though an efficient cause, is not necessarily a sufficient cause of a disease, and that the constitutional factor, on which much emphasis has been laid in recent years, must also be considered in the causation, especially in the case of non-infectious diseases, and is doubtless susceptible of analysis by modern methods.

In forecasting the activities of clinical science, Sir Frederick expressed his conviction that the scope for really controlled experiments applicable to the intact human body is limited. He suggested that there are relatively few experimental fields for clinical science besides those of cardiology and related subjects in which Sir Thomas Lewis is engaged, and the studies of Prof. Edward Mellanby on ,nutrition in relation to disease (see NATuRE of December 1, p. 830). On the other hand, there are many wide fields in laboratory science, and particularly those of biophysics and biochemistry, the cultivation of which will continue to benefit medicine.

Sir Frederick deprecated the growing tendency in Great Britain and elsewhere to distribute the funds provided for medical research in the endowment of the clinic at the expense of fundamental biological science, as he is convinced that such a policy will sterilise advance. In support of this conviction, he quoted Charcot's dictum that the clinic "without scientific renovation soon becomes a belated routine and, as it were, stereotyped".

In conclusion, Sir Frederick expressed the hope that the Royal Society, though its special duty is the encouragement of pure science, will continue to endow whatever fields of research might at any moment promise to offer most help towards progress, whether in the narrow region of clinical science or in the wider regions of pure science.

\title{
Maison de la Chimie, Paris
}

$\mathrm{T}$ $\mathrm{HE}$ inauguration of the Maison de la Chimie by the President of the French Republic, which had been postponed for a month owing to the assassination of the King of Yugoslavia at Marseilles, took place on December 1. An international gathering of unusual brilliance witnessed this important step towards the co-ordination of scientific endeavour. Twenty-four countries were represented, and among the delegates from Great Britain were Prof. H. E. Armstrong (Royal Society and Federal Council of Chemistry), Mr. W. A. S. Calder (Institution of Chemical Engineers), Prof. C. S. Gibson (Royal Society), Dr. T. A. Henry (Wellcome Research Institution), Mr. Emile Mond
(Federal Council of Chemistry and Chemical Society), Sir Robert Robertson (British Government), Mr. Richard Smith, Mr. Edwin Thompson and Prof. J. F. Thorpe (Institute of Chemistry), Mr. Thomas Pearson, of the International Chamber of Commerce and Sir Robert Cahill of the British Embassy. An excellent copy of the painting by Sir Thomas Lawrence of Sir Humphrey Davy was given to the "Maison de la Chimie" by a group of English chemists, whilst Mr. and Mrs. Emile Mond presented a replica of the bust of Faraday, the original of which is at the Royal Institution.

In the large and imposing hall, which will serve as meeting hall for future congresses, speeches 
were delivered by the French Minister of Education, by M. Behal of the Academy of Sciences, by Prof. E. Biilmann of Denmark and by Sir Robert Mond, emphasising the importance of the event and the debt which chemistry owes to Marcelin Berthelot, to whose memory the Maison de la Chimie is postal address and to share office facilities. Such affiliated bodies bring to the Centre their libraries. While remaining technically their property, the books are assembled and catalogued so that they are generally available. Each affiliated society pays about one shilling a year for each member

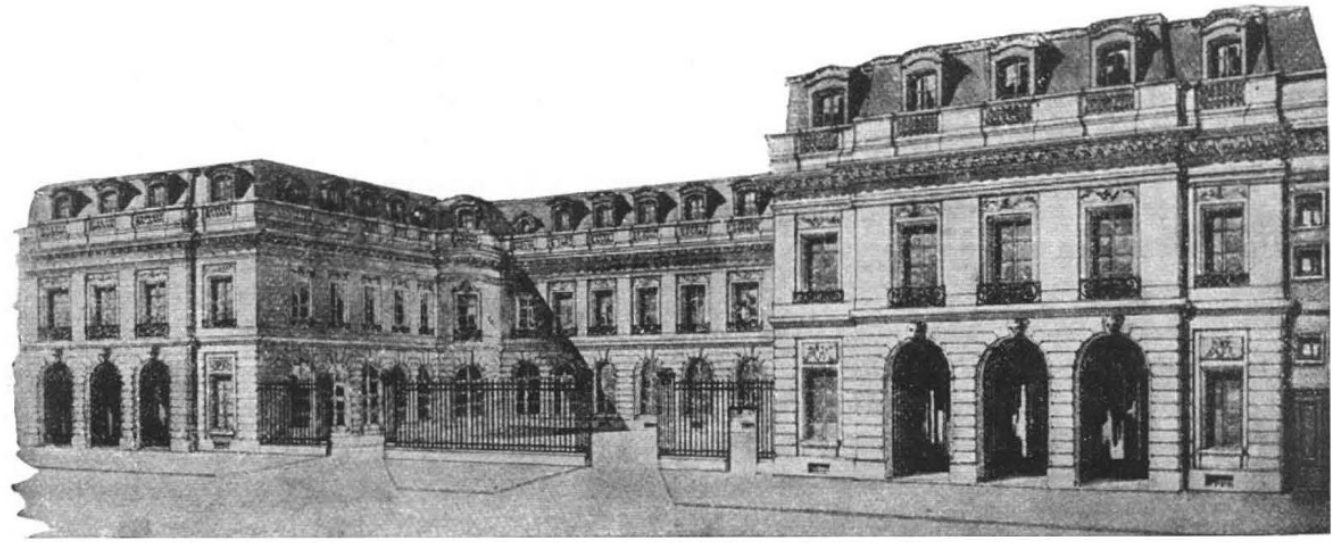

FrG. 1. Drawing of the front of the Maison de la Chimie.

dedicated. It was, in fact, in 1927, on the occasion of the Berthelot centenary, that an international appeal was made for funds for the erection of a centre for chemistry in Paris. To this fund sixty-five countries contributed, the total amounting to 25 million francs ; $£ 12,000$ was contributed from Great Britain, of which $£ 9,000$ came from Sir Robert Mond. The French Government gave to the Centre the historic building of La Rochefoucauld d'Estissac, rue St. Dominique, just behind the Chamber of Deputies (Fig. 1). Since 1931, extensive alterations have been made to this building, and two new wings added (Fig. 2) so that it is now admirably fitted for its new functions, which are to provide a meeting place for scientific societies and congresses and to supply information which it hopes to place at the disposal of those engaged in every branch of chemistry.

Its organisation covers three spheres of action :

(1) The "Centre Marcelin Berthelot", which supplies facilities for meetings and offices for scientific societies;

(2) A Centre of Chemical Documentation ;

(3) A Section of Technical Improvement.

With regard to the first, it is possible for a chemical society to have its own separate office within the building, or simply to have there a for the facilities afforded to its members (adherents).

The services offered by the Centre as a meeting place are very extensive. There are reception rooms, committee rooms (for 20-50 people), conference rooms (for 35-100 people), banquet rooms where up to 500 people can be entertained, and a

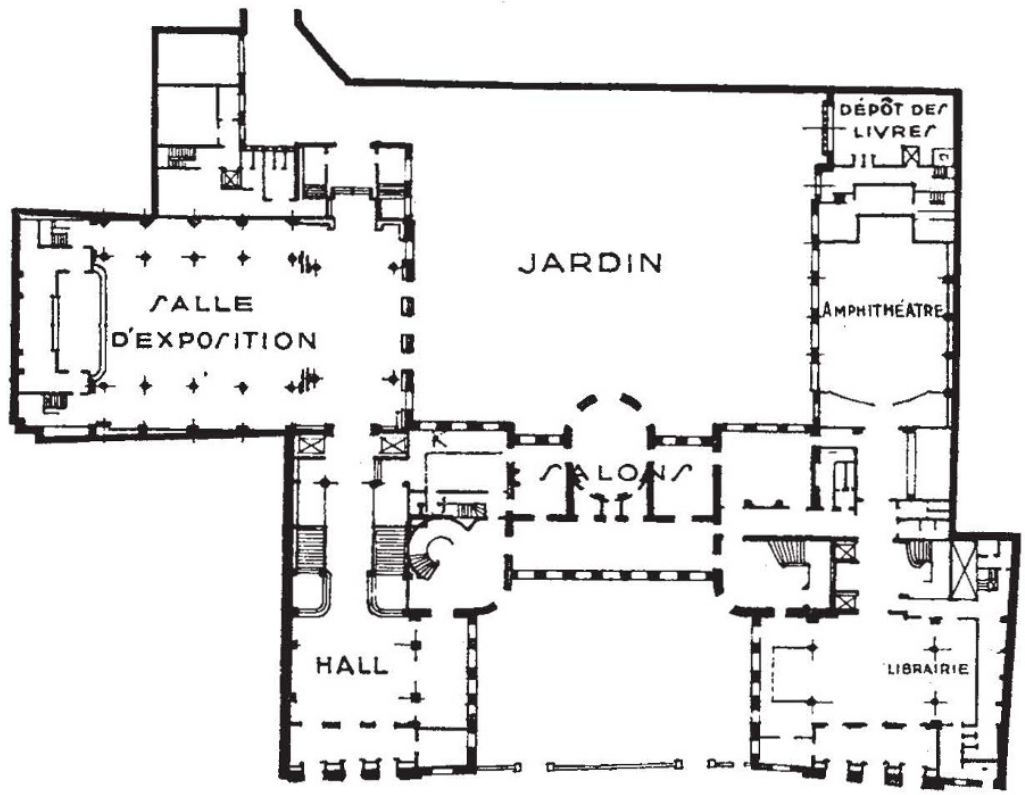

FIG. 2. Plan of the Maison de la Chimie.

large congress hall which accommodates about one thousand. The amphitheatre with some two hundred individual seats has extensive facilities for chemical experiments, and several projection screens that can be used simultaneously. Microscopic, cinematographic and direct projection of 
experiments are all provided for. Individual microphones for the use of deaf persons can be connected to thirty seats, apart from the usual microphones used by the lecturer.

The Centre of Documentation aims not only at being a depository of all chemical knowledge, but also hopes to select, extract and arrange such knowledge in a manner that will render it most useful and most readily available to the individual investigator. It should be able to prepare fairly complete bibliographic information upon any chemical subject referred to it, supply photographic copies of the less easily available material, and translate matter from one language into another when necessary. It follows that the members of its staff will have to be highly trained, and many of them will need that particular flair that enables one to pick up from a large amount of material the essential facts that are likely to be useful in a given problem-by no means an easy undertaking, yet one which must be faced.

As regards equipment, the reading room provides at present for thirty readers, and is equipped with special optical and acoustical apparatus, since the library includes not only printed material but also films, gramophone records, etc. A glass partition separates the reading room from a smaller 'conversation' room, also provided with telephones.

The abstracting of scientific papers, patents and other documents and the compilation of bibliographies is carried out in the Ludwig Mond Hall, on the third floor of the building. This department can draw upon the bibliographical resources of many other organisations in addition to those of the Maison de la Chimie. This last is affiliated to the Union française des Organismes de Documentation, the task of which is to co-ordinate the great libraries of Paris:

The third section of the Maison de la Chimie is the Centre of Technical Improvement (Centre de Perfectionnement technique), which aims at keeping industrial chemists and others in contact with the latest developments in science. This it does by means of special courses of lectures and exhibitions. Several such series of lectures have already been arranged, dealing with new types of materials, the organisation of industry, etc.

The success which has attended the centralisation of chemical documentation and facilities in the Maison de la Chimie has opened even wider horizons. A "Cité des Sciences" is now being suggested, which would bring together all branches of science, act as a link between them, co-ordinate their discoveries and render them available to workers in every field, and strengthen the international bonds which bind together all those engaged in scientific work.

Many people have helped to bring about the successful completion of the Maison de la Chimie, but there can be no doubt that credit rests largely with its active administrateur, M. Jean Gérard, to whose vision and energy every one of those present at the inauguration paid a well-deserved tribute. M. Gérard has been for many years the secretary of the International Union of Chemistry, takes an active part in the editing of Chimie et Industrie and is president of the Union française des Organismes de Documentation (corresponding to ASLIB in Great Britain).

\section{Large-Scale Plans of Great Britain}

$\mathrm{I}^{\mathrm{T}}$ is a widely accepted fact that, since the War, the national large-scale plans of Great Britain have been getting more and more out of date. The reductions of staff, effected as a result of the recommendations of the Geddes Committee of 1922, have made it impossible for the Ordnance Survey to keep the plans in a reasonable state of repair. This is all the more to be regretted because the reductions in question only produced a trifling economy in the national budget. A leading article discussing the present position was published in NaTURE of November 3, and if, as we may hope, an inquiry is to be held into this matter, a recent publication by the Director of the Ordnance Survey* will provide a sure foundation of fact upon which it can be based.

* Ordnance Survey. Professional Papers, New Series, No. 16: The National Plans (The Ten-Foot, Five-Foot, Twenty-five-inch, and Six-inch Scales). By Brigadier H. St. J.' L. Winterbotham, Director-General of the Ordnance Survey 1934. Pp. $112+27$ plates. (London: H.M. Stationery Offiee, 1934.) 48. 6d. net.
A list of some of the headings of the sections of the report will serve to give an idea of its character. We find amongst these headings :- early British property surveys ; foreign analogies; city scales ; first revisions ; a pre-War stocktaking ; reductions [of staff]; co-ordinates and sheet lines; levels and bench marks; areas ; boundaries ; the name book ; air revision ; plans for registration; plans for land valuation; surveys for tithes, and other interesting matters.

Brigadier Winterbotham rightly says that, in the main, the history of the Ordnance Survey in the century before this year, that is, since 1834, remains to be written, and he remarks that the history of our large-scale plans is particularly vital. "The times are difficult. Short cuts and next bests suggest themselves in a variety of ways. It is time to take stock of where we are going."

Two generations ago, a commission of inquiry 